\title{
Os desenhos da cidade: as representações da cidade do Natal no século XVII
}

Rubenilson Brazão Teixeira ${ }^{1 *}$

${ }^{1}$ Universidade Federal do Rio Grande do Norte, Natal/RN - Brasil

\section{RESUMO}

A cartografia histórica referente ao século XVII privilegiou alguns poucos núcleos urbanos do Brasil, com desenhos relativamente precisos de sua área urbana e de seu entorno. Não parece ter sido o caso para a maioria das localidades então existentes, como Natal/RN, para a qual é de se questionar até que ponto os poucos mapas daquela época representam a realidade urbana da cidade de então. Este artigo discute essa questão a partir da representação gráfica da cidade por um conjunto de mapas, interpretando-os a partir do confronto com manuscritos coevos existentes sobre a cidade. Em que pese algumas incongruências e lacunas, os mapas analisados de fato permitem uma percepção relativamente precisa sobre o que era a cidade e seu entorno no período em apreço.

Palavras-chave: desenho; representação; cartografia; Natal; século XVII.

\section{Drawings of the city: the representation of Natal city in the $17^{\text {th }}$ century}

\section{ABSTRACT}

Historical cartography regarding the $17^{\text {th }}$ century privileged a few urban nuclei of Brazil, producing fairly precise drawings of their urban area and surroundings. Apparently, this has not been the case for most of the existing localities, like Natal/RN, to which one may question to what extent the few maps of that time represent the city's urban reality of that period. This article focuses on graphic representation of Natal in a set of maps, by interpreting and confronting them with manuscripts about the city that have been contemporary with 
those maps. Despite some inconsistencies and gaps, it is demonstrated the maps analyzed portray a relatively precise perception of what the city was at that point.

Keywords: drawing; representation; cartography; Natal; $17^{\text {th }}$ century.

\section{Los diseños de la ciudad: las representaciones de la ciudad de Natal en el siglo XVII}

\section{RESUMEN}

La cartografia histórica referente al siglo XVII privilegió algunos pocos núcleos urbanos de Brasil, con diseńos relativamente precisos de su área urbana y de su entorno. No parece haber sido el caso para la mayoría de las localidades entonces existentes, como Natal/RN, para la cual es cuestionable hasta qué punto los pocos mapas de aquella época representan la realidad urbana de esa ciudad. Este artículo discute esta cuestión a partir de la representación gráfica de la ciudad por un conjunto de mapas, interpretándolos a través del confronto con manuscritos actuales existentes sobre la ciudad. A pesar de algunas incongruencias y lagunas, los mapas analizados de hecho permiten una percepción relativamente precisa sobre lo que era la ciudad y su entorno en el periodo estudiado.

Palabras clave: diseño; representación; cartografía; Natal; siglo XVII.

\section{Considerações iniciais ${ }^{1}$}

O desenho é um modo eficaz e muito atual de representação da cidade. No que se refere especificamente ao Brasil, desde o século XVI que existem mapas de todo o território colonial, com informaçóes preciosas especialmente sobre o litoral, área de contato imediato com o colonizador português, mas também de outras nacionalidades que visitaram essas terras. Também existem plantas bastante precisas de alguns núcleos urbanos desde a primeira metade do século XVII, a exemplo de Salvador, de Filipeia de Nossa Senhora das Neves, atual João Pessoa, ou Olinda. Tanto os mapas em escala geográfica, regional, quanto as plantas dessas cidades demonstram um relativo grau de precisão, apesar dos meios técnicos limitados de então.

Contudo, nem todos os núcleos urbanos mais antigos do país tiveram a sorte de terem sido representados graficamente como os casos citados acima, de sorte que é de se questionar

\footnotetext{
${ }^{1}$ Este artigo é resultado de pesquisa que contou com o apoio de bolsa de produtividade do CNPq. Registramos aqui nossos agradecimentos ao CNPq.
} 
até que ponto as poucas e raras representaçóes dessas localidades correspondem de fato à realidade urbana da época ou se, pelo contrário, são meramente símbolos gráficos utilizados apenas para localizá-las em determinado território. Em outras palavras, será que as representaçôes gráficas, nesses casos, podem nos dizer algo sobre a sua forma urbana inicial, bem como sobre o seu sítio e entorno imediato?

Essa questão central vai guiar a nossa análise neste artigo. Enfocamos o caso da cidade do Natal, capital da antiga capitania do Rio Grande (do Norte). Fundada em 1599, é a quinta mais antiga aglomeração do Brasil a receber, desde o seu nascimento, o título de cidade, dentro da hierarquia urbana então em vigor. Apesar do seu importante papel militar e geoestratégico ao longo de sua história, parece não ter recebido alguma atenção especial no que se refere ao desenho enquanto concepção de projeto.

Diversos mapas que representam o vasto território brasileiro desde o início do século XVII indicam efetivamente a presença da cidade do Natal na costa potiguar, mas se limitam a indicar nominalmente a localização da urbe, ainda que alguns poucos esbocem, além da indicação onomástica, algum desenho da cidade em si. Ora, são precisamente esses poucos mapas que nos interessam neste trabalho. Estamos interessados nos que foram produzidos na primeira metade do século XVII, ou seja, ao longo dos primeiros cinquenta anos de sua existência.

Existe uma ampla discussão teórica sobre a cartografia, notadamente a cartografia histórica, que envolve aspectos ou dimensóes ideológicas, simbólicas, da semiologia ou do imaginário, entre outros ${ }^{2}$. Parte dessa discussão questiona, por exemplo, uma leitura factual, descritiva e objetiva de mapas históricos, afirmando a necessidade epistemológica de ir além e de "desconstruí-los", isto é, de transcender a sua mera representação e avançar na sua interpretação, retirando deles, assim, uma pretensa "neutralidade". A interpretação poderia revelar, por exemplo, tensóes e interesses de grupos, inclusive escondendo ou negando determinadas dimensôes sociais que terminam por legitimá-las ${ }^{3}$. Nesse sentido, cabe ao pesquisador se questionar, por exemplo, se eventuais incongruências entre a representação e a realidade são fruto da ignorância, ou se elas foram propositais, ou ainda se resultaram desses e de outros fatores conjuntamente. Da mesma forma, representaçóes relativamente ou mesmo altamente precisas também não estão isentas de questionamentos.

O presente trabalho assume claramente as duas dimensóes acima referidas, de representação e de interpretação da cartografia histórica, as quais definem, inclusive, a estrutura do artigo. No primeiro item, que se refere à "representação da cidade”, buscamos definir textualmente ao final do item, após a análise descritiva dos mapas selecionados, uma configuração físico-espacial, mas também social e econômica, da cidade do Natal na primeira metade do

\footnotetext{
${ }^{2}$ Por exemplo, ALBUQUERQUE e OLIVEIRA, 2012.

${ }^{3}$ Ver, a esse respeito, HARLEY, 1992, p. 10-13. Um pesquisador brasileiro de leitura obrigatória no campo da cartografia histórica é Paulo Knauss de Mendonça. Ver, por exemplo, KNAUSS; RICCI; CHIAVARI, 2010.
} 
século XVII, para isso nos baseando tão somente no que dizem os mapas selecionados e examinados. Ou seja, trata-se de uma análise interna aos mapas. Não questionamos, nesse momento, se o que eles representam corresponde de fato à realidade. Produzidos no período em apreço, eles foram organizados cronologicamente, do mais para o menos antigo. Cada mapa é reproduzido na íntegra e com um recorte ampliado do núcleo urbano da cidade propriamente dito e de seu entorno.

No segundo item, o da "interpretaçáo da cidade", procuramos desvendar em que medida a configuração definida a partir dos mapas de fato corresponde à realidade da época, utilizando-nos para isso do confronto das informaçôes gráficas com outras fontes documentais, escritas, grosso modo, coevas àquelas e, eventualmente, estudos prévios sobre o tema. Nesse sentido, concordamos com Jorge Pimentel Cintra que, na mesma linha de raciocínio de Brian Harley, afirma, em sua proposta de técnicas de leitura de mapas históricos, que

Um mapa é um documento, mas como qualquer outro, precisa ser analisado com cautela e espírito crítico, confrontando com outras fontes. A análise aqui proposta é portanto um ponto de partida, e náo de chegada (CINTRA, 2015, p. 786. Grifos nossos).

Jorge Cintra defende, entre outros pontos, "a arte de ver" e de "interrogar os mapas (p. 786)". Ainda que ele tenha se baseado nos postulados teóricos de Aristóteles para desenvolver sua proposta, que não estão em pauta neste trabalho, suas ideias se assemelham, grosso modo, às etapas de representação e de interpretação aqui propostas. Na primeira, tentamos simplesmente "ver" o que os mapas representam; na segunda, vamos além, tentando "interrogá-los" a partir do confronto com outras fontes. Trata-se agora de uma análise externa aos mapas, mesmo que eles continuem em pauta. Nós os interrogamos no intuito de saber se e em que medida eles fornecem bases seguras para nos informar como era de fato a realidade da cidade do Natal e de seu entorno na primeira metade do século XVII, tanto em termos físico-espaciais principalmente, quanto em termos sociais e econômicos.

Isso dito, cabe destacar que esse é apenas o "ponto de partida" do processo de interpretação da cartografia histórica, pois não avançamos na discussão quanto às intençôes que subjazem a feitura e o porquê do tipo de informação que os mapas contêm, com vistas a apontar as explicaçôes de natureza social, política, econômica, simbólica ou outra que justificaram a sua produção. Não avançamos na reflexão sobre a natureza, os motivos, as tensões ou o porquê da presença ou ausência de determinadas informaçôes, entre outros, eventualmente detectados na análise dos mapas, para o quê o aporte das ciências humanas em geral é fundamental. Buscar explicaçôes sobre o "porquê" eles representam o que representam (ou deixam de representar) exigiria um trabalho muito mais amplo, que náo cabe nos limites deste artigo.

As informaçôes, gráficas ou textuais, disponíveis são extremamente sumárias, muito aquém do que a nossa curiosidade exige, mas nisso reside justamente o interesse do estu- 
do. Queremos extrair tanto quanto possível dessas fontes informaçôes sobre forma urbana inicial e sobre o entorno de uma cidade periférica da qual pouco se sabe a esse respeito. A Figura 1 indica a localização da cidade do Natal no mapa atual do Estado do Rio Grande do Norte, bem como a área correspondente à cidade na primeira metade do século XVII, sobre a imagem aérea de uma parcela ínfima da Natal atual, no intuito de auxiliar o leitor menos familiarizado com a cidade.

Figura 1: O Rio Grande do Norte e imagem da cidade do Natal, na área correspondente ao sítio inicial da cidade.
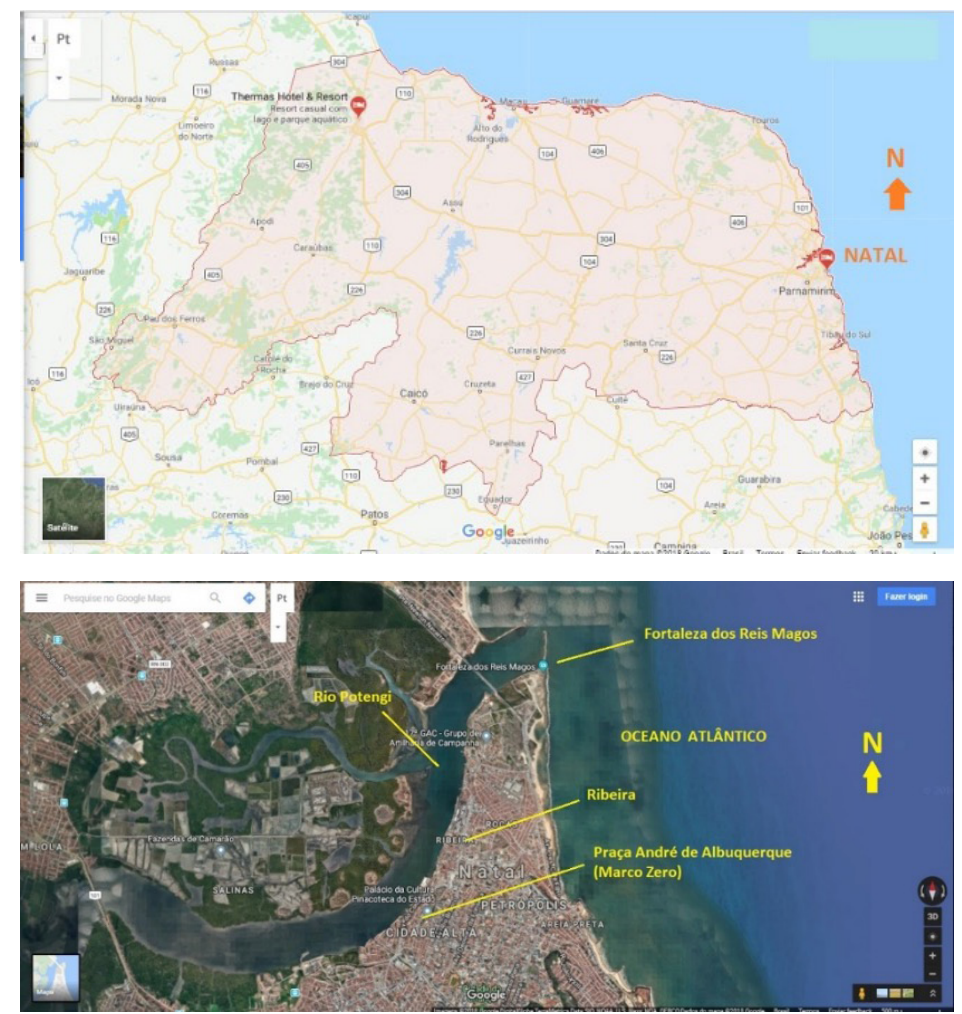

Fontes: Google maps, modificados pelo autor.

\section{A representação da cidade}

Como dissemos, nesse primeiro item queremos tão somente "ver" o que nos dizem as representaçóes de Natal e seu entorno nos mapas selecionados. Foram selecionados seis mapas antigos, grosso modo confeccionados na primeira metade do século XVII. Alguns deles existem em mais de uma versão ou foram visivelmente copiados de mapas mais antigos. Há ainda um mapa atual, que reproduz, no entanto, parte de um mapa antigo, totalizando sete mapas. Começamos com a Figura 2, a seguir: 
Figura 2: A foz do Rio Grande: planta geral e recorte ampliado (1609).
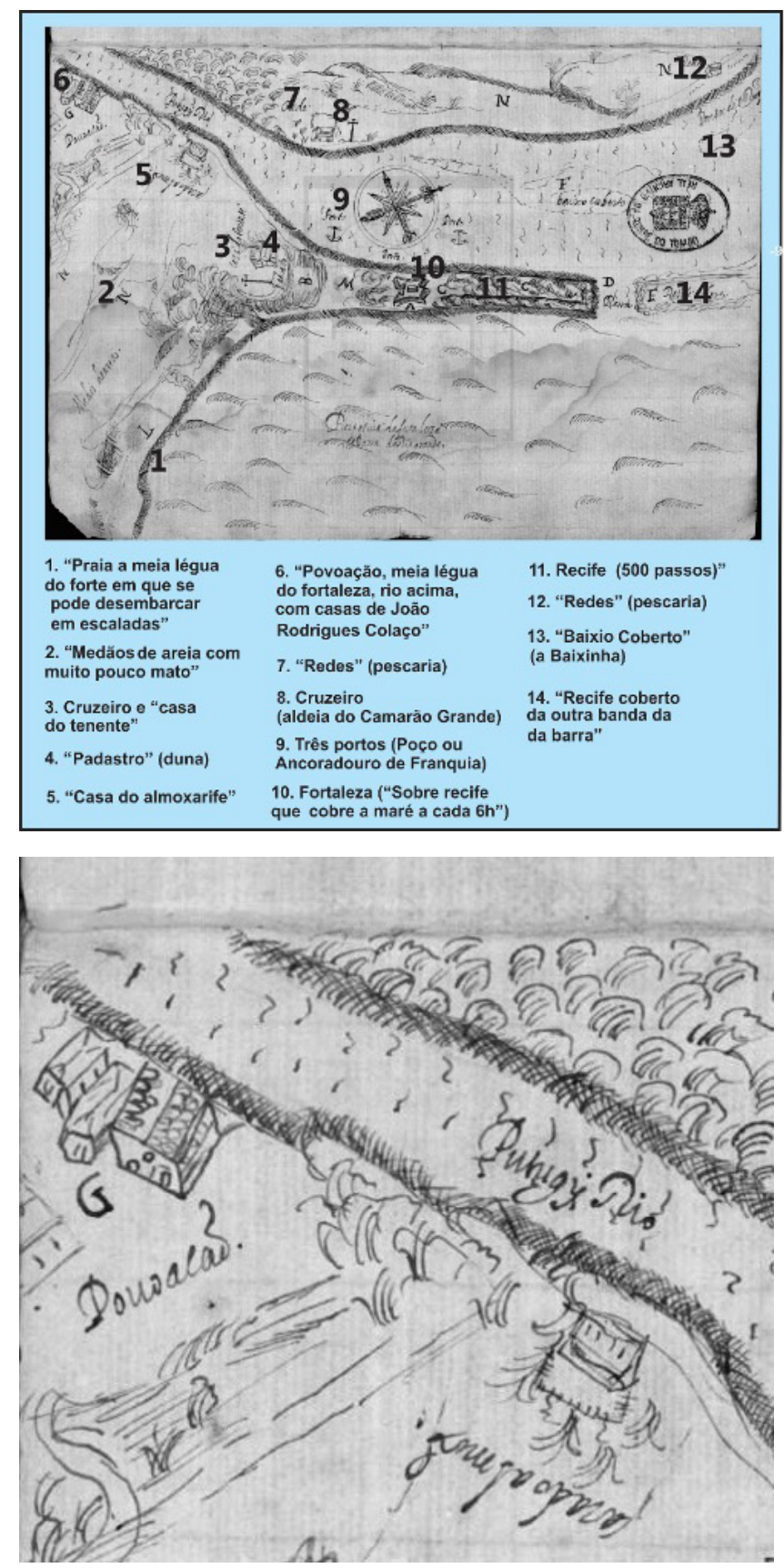

Fonte: MORENO, Diogo de Campos. Relação das Praças Fortes coisas de importância que Sua Majestade tem na costa do Brasil. 1609. Arquivo Nacional da Torre do Tombo. (PT/TT/MR/1/68). Imagem cedida pela ANTT'́

\footnotetext{
${ }_{4}^{4}$ Disponível em: https://digitarq.arquivos.pt/viewer?id=4242957. Ver imagem PT-TT-MR-1-68_m0005.
} TIF. Acesso em: 5 ago. 2019. 
Esse mapa faz parte de um conjunto de pranchas atribuídas a Diogo de Campos Moreno. $\mathrm{O}$ documento original é acompanhado de um texto, apresentado na Figura $2 \mathrm{em}$ forma de notas explicativas ${ }^{5}$. Trata-se do mapa mais antigo de que se tem conhecimento da cidade do Natal, fundada apenas dez anos antes. Entre outros itens dignos de informação, ele mostra alguns elementos da ocupação colonial em seus primórdios, identificados pelos números 3, de 5 a 10 e 12. Destaca-se o número 6, representado pela letra "G" no documento original, como aparece no recorte ampliado. Refere-se à "povoação, meia légua da fortaleza, rio acima, com casas de João Rodrigo Colaço", o primeiro capitão-mor do Rio Grande. O mapa parece náo apresentar a cidade toda, e fora do "núcleo urbano" propriamente dito, localizado muito perto do rio, chamam atenção algumas construçôes esparsas em direção à Fortaleza dos Reis Magos (3 e 5), bem como a exploração da pesca no Rio Potengi (7, 9 e 12).

Figura 3: Rio Grande capitania de Sua Majestade (c. 1616). Planta geral e recorte ampliado.
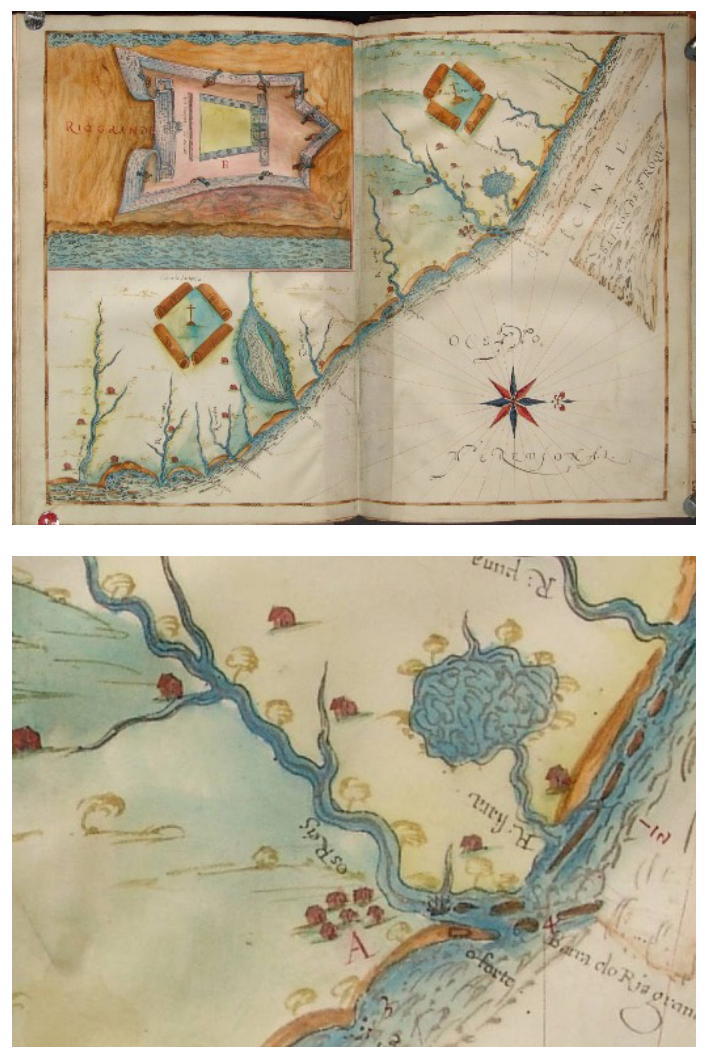

Fonte: MORENO, Diogo de Campos. Livro que dá razão ao Estado do Brasil. Biblioteca Municipal do Porto $(\mathrm{BMP})^{6}$

\footnotetext{
${ }^{5}$ As notas foram transcritas por MEDEIROS FILHO, 1997, p. 93-95.

${ }^{6}$ A cópia mais antiga existente dos mapas dessa obra rara é de 1616. Esse mapa está disponível no acervo digital da BNP, em: http://arquivodigital.cm-porto.pt/Conteudos/Conteudos_BPMP/MS-126/MS-126_item1/ P252.html. Acesso em: 5 jun. 2018.
} 
Atribui-se o mapa reproduzido na Figura 3 ao cosmógrafo Joáo Teixeira Albernaz I (o Velho), o qual acompanha o texto intitulado "Rio Grande capitania de sua Majestade", no "Livro que dá razão do Estado do Brasil", de Diogo de Campos Moreno ${ }^{8}$. Além da cidade do Natal e da fortaleza, ainda sem sua capela central, o mapa mostra duas aldeias indígenas, uma das quais, na margem esquerda do Rio Potengi, é a do chefe indígena Camarão. A outra está situada nas proximidades da lagoa de Guaraíras, hoje município de Arez, portanto, bem distante do sítio inicial da cidade. No recorte, vemos no ponto "A" a cidade, denominada "os Reis", representada por um conjunto de casas muito simples, a localização da fortaleza e uma série de edificaçóes esparsas no território, acompanhando a margem do Rio Potengi e de seus afluentes?.

Figura 4: Veroveringe van Rio Grande in Brasil (1633). Estampa completa e recorte ampliado. Seção de Mapoteca e Iconografia do Ministério das Relaçōes Exteriores no Rio de Janeiro, sob a notação: VEROVERINGE VAN RIO GRANDE IN BRASIL (1633).
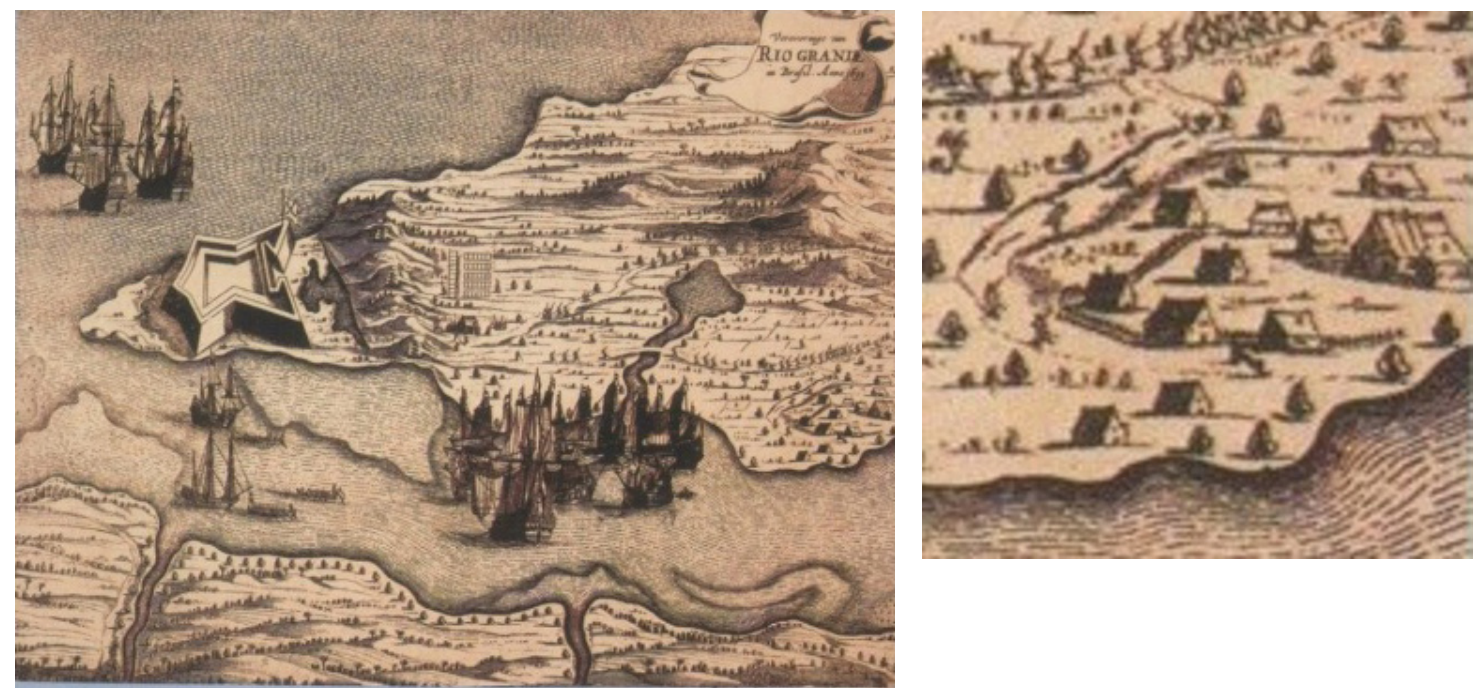

Fonte: Seção de Mapoteca e Iconografia do Ministério das Relaçôes Exteriores no Rio de Janeiro. ${ }^{10}$

\footnotetext{
${ }^{7}$ A capitania era de "Sua Majestade" porque havia sido devoluta à Coroa após o fracasso de sua ocupação e exploração pelo donatário João de Barros e seus filhos, quando da instituição das capitanias hereditárias, a partir de 1532.

${ }^{8} \mathrm{O}$ texto foi reproduzido na íntegra em SLUITER, 1949.

${ }^{9}$ Existe uma reproduçấo desse mapa no "Livro em que se mostra a descrição de toda acosta do estado do Brasil e seus portos, barras e sondas delas", de João Teixeira Albernaz, o moço, cosmógrafo real, e datado de 1627. Não está sendo reproduzido aqui.

${ }^{10}$ Cópia digital disponível em http://www.sudoestesp.com.br/file/colecao-imagens-periodo-colonial-rio-grande-norte/685/. Acesso em: 5 jun. 2018.
} 
A Figura 4 reproduz uma estampa de autor não identificado, Veroveringe van Rio Grande in Brasil, ou a "conquista do Rio Grande no Brasil" pelos holandeses, em 1633. A Fortaleza dos Reis Magos está visivelmente superdimensionada. Há um acampamento holandês e uma edificação por trás das dunas próximas à fortaleza. Navios holandeses estão fundeados na foz do Rio Potengi e no mar; tropas avançam em direção à fortaleza, por meio de dois caminhos, um dos quais passando perto da cidade. Entre a fortaleza e a cidade se localiza um córrego ou afluente do Potengi, com sua nascente numa lagoa; sobre o córrego há uma ponte, que faz parte de um dos caminhos utilizados pelas tropas holandesas se dirigindo à fortaleza. O recorte mostra a cidade do Natal, aparentemente com alguma cerca ou paliçada em parte dela, com alguns soldados margeando a cerca, talvez representando portugueses tentando defendê-la. As casas sáo dispersas, com diferentes dimensôes.

Há outra estampa do período holandês, intitulada Afbeelding van Tfort opRio Grande ende Belegeringhe, publicada no livro do geógrafo holandês Joannes de Laet, em 1644 (LAET, 1912, p. 340-341), que também ilustra o cerco da fortaleza, mas difere levemente da estampa da Figura 4. O riacho entre a fortaleza e a cidade que tem como nascente uma lagoa é denominado, no livro de Laet, de "rio da cruz" (kruy's rivier); um caminho, e não dois, liga a cidade - chamada de "aldeia dos portugueses" (het dorp van de portugezen) - à fortaleza, antes denominada de Forte Três Reis, agora Forte Ceulen. A cidade também é representada de forma aproximada à da Figura 4, mas sem caminhos ou paliçada no seu entorno, e com destaque para uma edificaçáo de grande porte. Perto da fortaleza se encontra o mesmo acampamento militar, mas com três baterias de morteiros sobre as dunas; a edificação que lhe fica próxima também é representada, mas é identificada como o alojamento de Mathias van Ceulen, comandante da expedição holandesa que conquistou a capitania em 1633 e em homenagem ao qual a fortaleza foi renomeada. Do outro lado do rio, há outro assentamento. Essa estampa é acompanhada de um texto bastante detalhado sobre a conquista do Rio Grande, de autoria de Joannes de Laet, na mesma obra. No seu relato, ele descreve o ataque e rendição dos soldados da fortaleza, bem como a ocupaçáo da "vila de Natal" (p. 341-346)"11. A estampa ${ }^{12}$ não está sendo reproduzida aqui em razão das delimitaçôes do artigo.

\footnotetext{
${ }^{11}$ Diferentemente dos portugueses, os holandeses parecem não dar muita importância à hierarquia urbana das localidades, pelo menos é o que ocorre no caso de Natal. Neste e em outros escritos, os termos "aldeia", "vila" ou "cidade" são usados para designá-la, a crer nas traduções dos textos originais para o português. Sobre esse assunto, ver TEIXEIRA, 2019.

${ }^{12}$ Uma reproduçáo em boa resolução se encontra em: https://commons.wikimedia.org/wiki/File:AMH6715-KB_Bird\%27s_eye_view_of_the_fort_of_Keulen_near_the_Rio_Grande_and_environs.jpg. Acesso em 7 mai. 2018.
} 


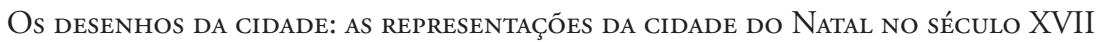

Figura 5: O Rio Grande. Mapa completo e recorte ampliado (1640).
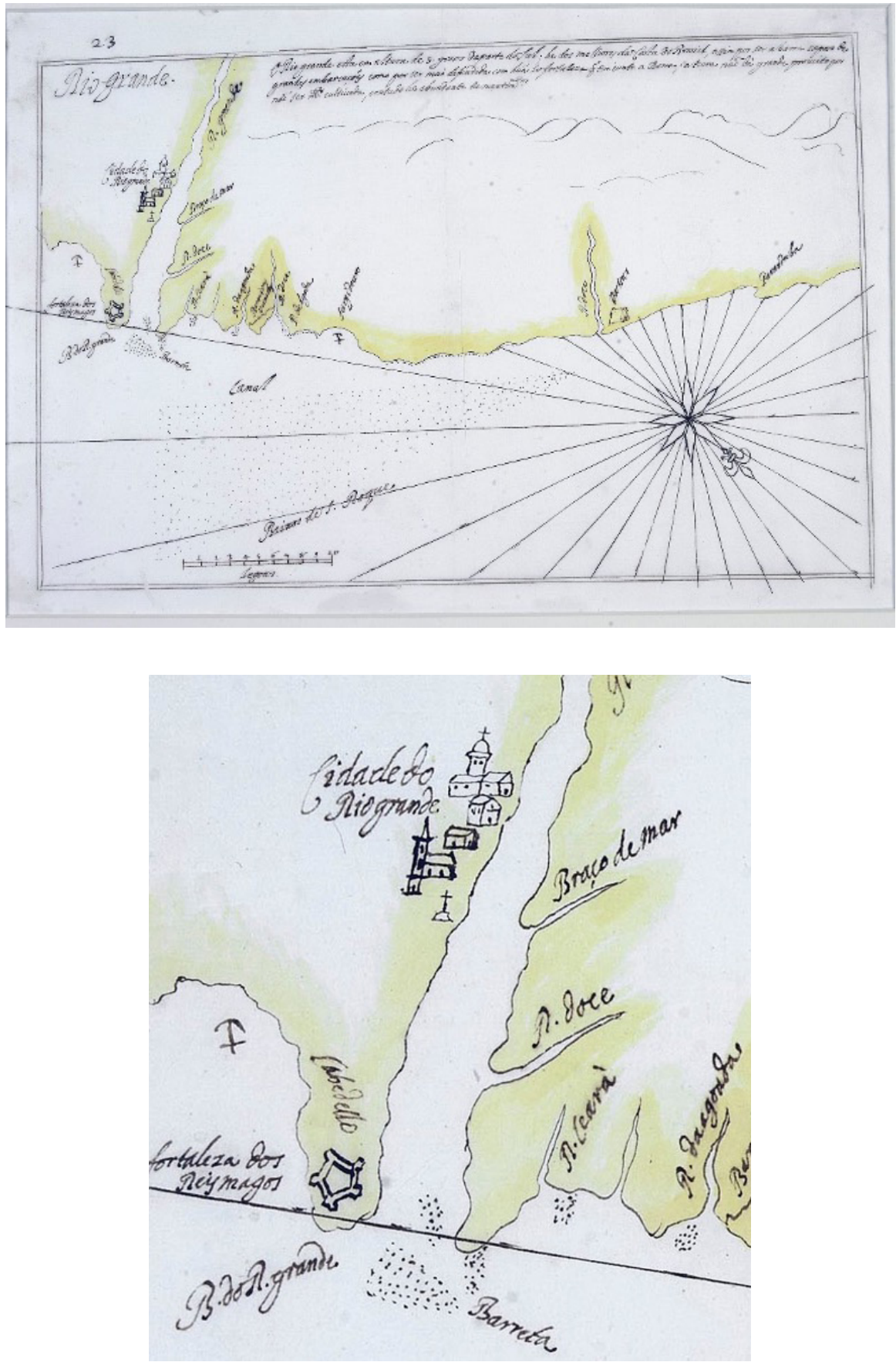

Fonte: Atlas da costa do Brasil. Biblioteca Nacional de Portugal (BNP). 
A Figura 5 faz parte de um conjunto de mapas representando toda a costa do Brasil, de autoria desconhecida e publicado em 1640. Esse Atlas se assemelha ao Atlas de João Teixeira Albernaz I, do mesmo ano, que veremos adiante. Duas pranchas representam a costa da capitania do Rio Grande, uma das quais mostra a cidade do Natal. Além da foz do rio, da Fortaleza dos Reis Magos e da cidade propriamente dita, denominada de Cidade do Rio Grande, como mostra o recorte ampliado, o mapa ainda localiza vários rios da costa para além do Potengi. Na cidade, há dois edifícios de maior porte, talvez a igreja e a sede do Senado da Câmara, e um mobiliário que parece ser um cruzeiro. No topo da prancha, encontra-se o seguinte texto:

O Rio Grande está em altura de cinco graus da parte do sul, é dos melhores da costa do Brasil, assim por ser a barra capaz de grandes embarcaçóes como por ser mui defendida com uma fortaleza que tem junto à barra; a terra não dá grande proveito por não ser cultivada, contudo é abundante de mantimentos.

Figura 6: A Fortaleza dos Reis Magos, a barra do Rio Grande e "a cidade dos Reis" (Natal) - c. 1640. Mapa completo e recorte ampliado.
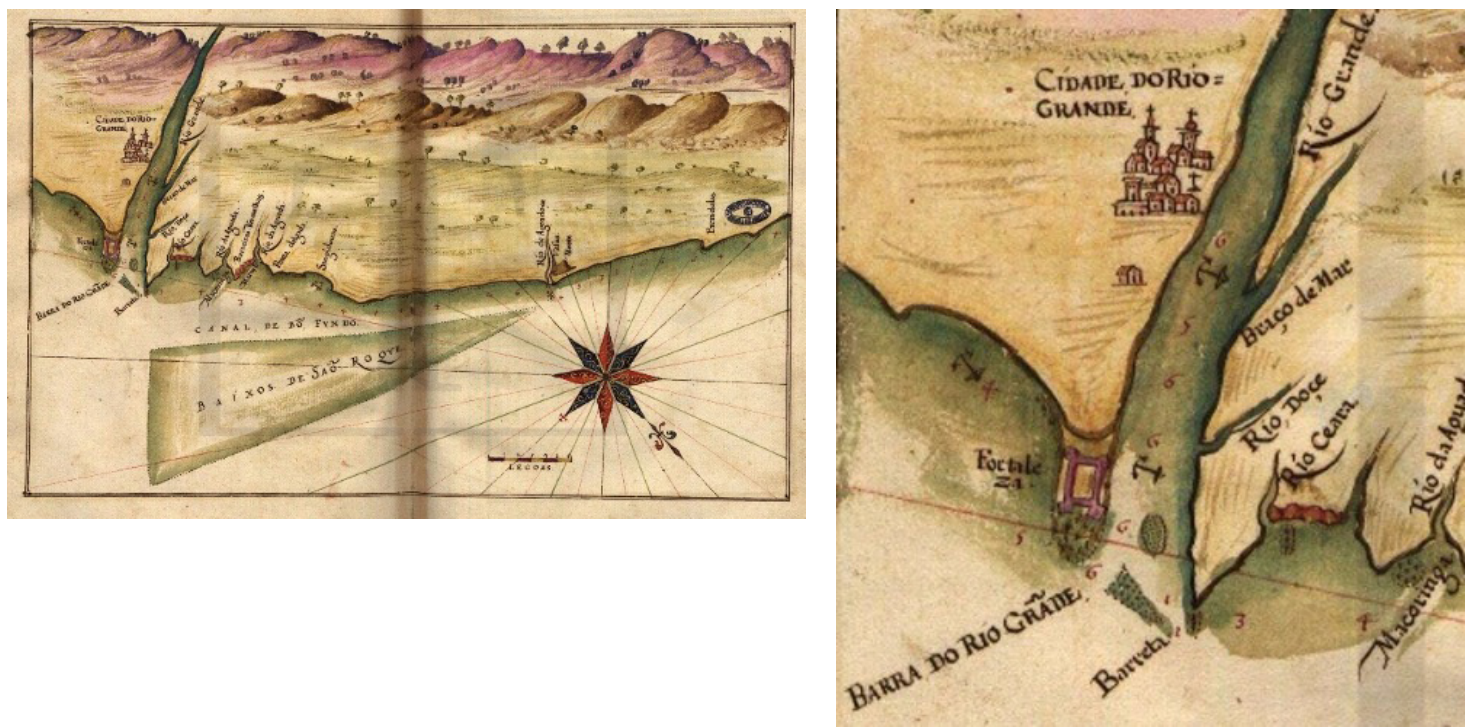

Fonte: ALBERNAZ I, João Teixeira (o Velho). Descrição de todo o marítimo da Terra de Santa Cruz chamado vulgarmente, o Brasil. Arquivo Nacional da Torre do Tombo. (PT/TT/CART/162). Imagem cedida pela $\mathrm{ANTT}^{13}$.

\footnotetext{
${ }^{13}$ Ver https://digitarq.arquivos.pt/viewer?id=4162623. Prancha PT-TT-CRT-162_m0134. Acesso em: 5 jan. 2019.
} 
As informaçôes contidas no mapa da Figura 6 são semelhantes às do mapa anterior, um devendo ser cópia do outro, sem que seja possível definir qual é o original. Ambos são acompanhados de um breve texto explicativo descrevendo o litoral e a foz do Potengi ${ }^{14}$ e foram publicados por volta de 1640 . O da Figura 6, porém, com uma representação gráfica mais colorida e viva, apresentando Natal com maior imponência, com mais edificaçôes. Apresenta, ainda, uma edificação a meio caminho entre a cidade e a fortaleza, e uma praça mais definida, no centro da qual se localiza o que pode ser o pelourinho, o cruzeiro ou mesmo uma forca, além de mostrar as edificaçóes que a delimitam. Esse mapa, como o anterior, denomina Natal de a Cidade do Rio Grande.

Figura 7: Praefectura de Paraiba, et Rio Grande (1647, c. 1665). Mapa completo e recorte ampliado.
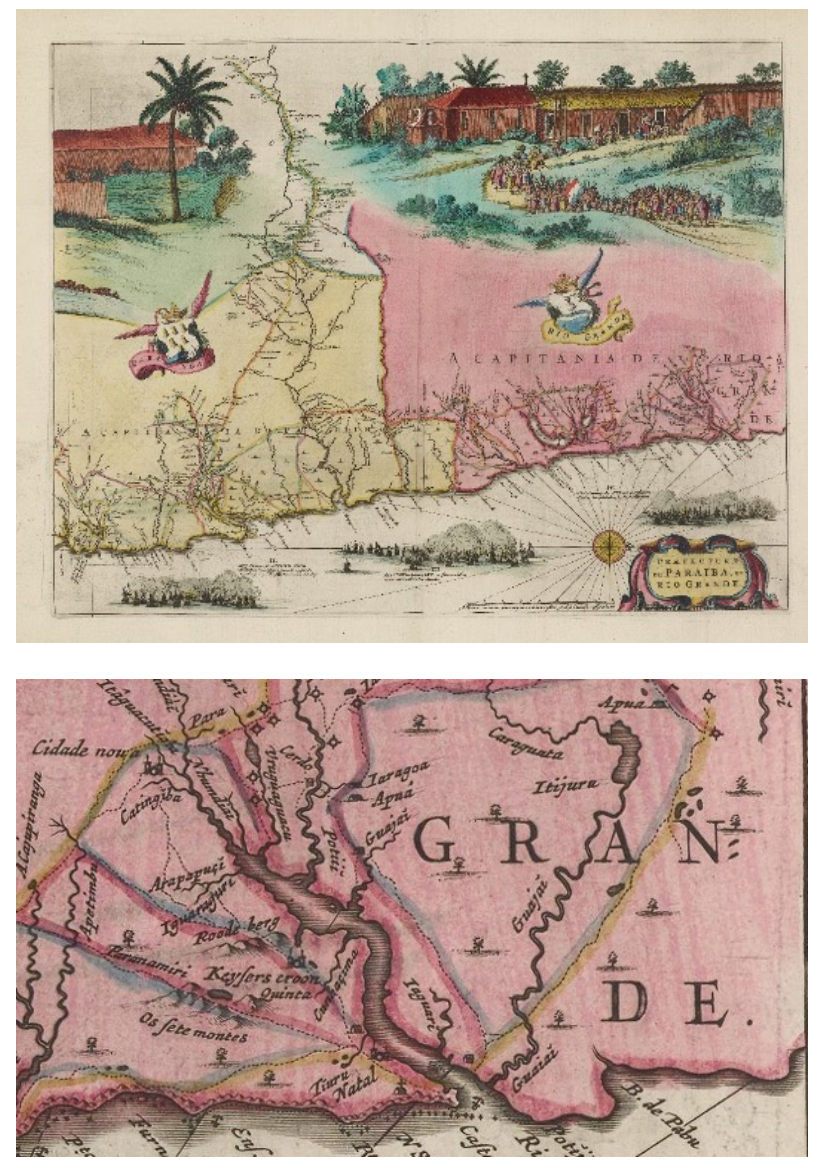

Fonte: BLAEU, Joan. Praefectura de Paraiba, et Rio Grande. Atlas Maior ... Amsterdam, 1665. David Rumsey Historical Map Collection. ${ }^{15}$

\footnotetext{
${ }^{14} \mathrm{O}$ da Figura 6 tem um texto um pouco mais detalhado, não reproduzido aqui.

${ }^{15}$ Mapa disponível em https://www.davidrumsey.com/luna/servlet/detail/RUMSEY 8 1 282902 9005440

7:Praefectura-De-Paraiba,-Et-Rio-Gran. Acesso em: 5 jun. 2018.
} 
O mapa da Figura 7 é parte integrante do Atlas Maior Sive Cosmographia Blaviana, Qua Solvm, Salvm, Coelvm, Accvratissime Describvntvr, publicado em 1665. Reproduz outro mapa holandês, também muito conhecido, de mesmo título, publicado em 1647, durante a ocupação holandesa do atual Nordeste brasileiro, de autoria de Georg Marcgraf. Mostra as capitanias do Rio Grande e da Paraíba. Um estudo aprofundado de qualquer dos mapas, o de 1647 ou este de 1665, cópia do anterior, revelaria uma série de informaçóes interessantes sobre o processo de ocupação dessa faixa litorânea, como a existência de povoados, aldeias indígenas, fortalezas, engenhos, currais e caminhos. Nosso interesse, porém, se resume à cidade do Natal e o seu entorno, e nesse sentido reproduzimos aqui a planta feita por Luana Cruz, baseada no mapa de Marcgraf, de 1647, no trecho que envolve a região de Natal e seu entorno. As informaçóes que a autora colheu são exatamente as mesmas do mapa de Joan Blaeu, de 1665, reprodução daquele. Nele se localizam: a Fortaleza dos Reis Magos, chamada de Castelo Keulen ${ }^{16}$; a cidade - denominada Natal - ao norte de um córrego que nasce aparentemente numa lagoa, chamada de Tiuru, e deságua no Potengi, e ao sul do qual existe uma edificação; o Keisers croon, cuja representação parece ser de uma igreja; uma igreja isolada, ao norte da cidade, chamada de Nossa Senhora dos Montes; uma "cidade nova", mais ou menos a sudoeste de Natal; um local chamado Itinga; currais de gado e caminhos, além de uma edificação localizada na foz e na margem esquerda do Potengi. Luana Cruz não representou, no mapa da Figura 8, a Fortaleza dos Reis Magos e se limitou a reproduzir o riacho sem nomear o Turiu, informaçóes que também estão presentes no mapa de Marcgraf. O riacho aparece abaixo do nome "Natal".

Figura 8: Natal e seu entorno.

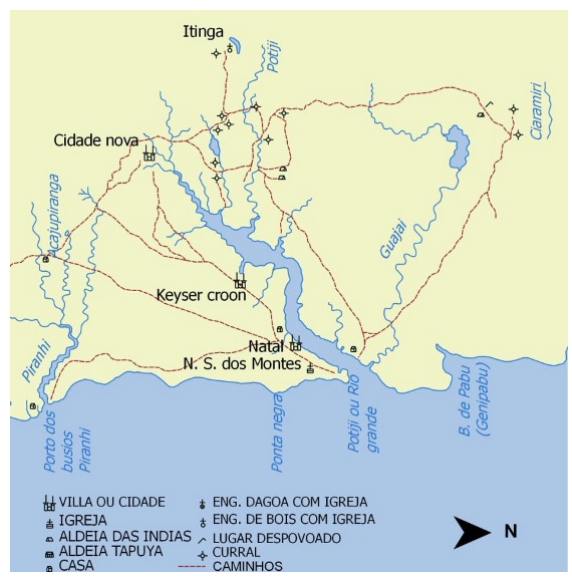

Fonte: desenho elaborado por Luana Cruz e Hélio J. de Oliveira Jr. (CRUZ, 2015, p. 95) ${ }^{17}$ sobre original de MARCGRAF (1647).

\footnotetext{
${ }^{16}$ Keulen, aqui escrito com "K" é, como vimos, uma homenagem a Mathias van Ceulen, comandante da expedição holandesa que conquistou o Rio Grande em dezembro de 1633.

${ }^{17}$ As informações contidas são as mesmas do mapa da Figura 7.
} 
O conjunto de mapas aqui apresentado possibilita, como nota conclusiva deste item, apontar uma breve descrição de Natal na primeira metade do século XVII: Natal era uma cidade fundada a certa distância da Fortaleza dos Reis Magos; o núcleo propriamente dito assumia uma forma urbana aparentemente irregular na maioria das representaçôes, ainda que em alguns casos ela aparente certa regularidade, em torno de uma praça central. Era dotada de um casario esparso, mais ainda no seu entorno, nesse caso com edificaçóes localizadas em áreas que poderíamos chamar de rurais. Deveriam ser sedes de fazendas de criação de gado; também se explorava a pesca no entorno da cidade. Entre a cidade e a Fortaleza dos Reis Magos aparecem edificaçóes isoladas; o casario urbano era humilde, mesmo que algumas representaçôes pareçam dizer o contrário; algumas representaçôes destacam claramente a existência de edifícios oficiais no seu interior, como a igreja e a casa de câmara e cadeia, mas também fora desse núcleo urbano, como a Igreja Nossa Senhora dos Montes e especialmente a Fortaleza dos Reis Magos. Novos assentamentos urbanos já dão sinal de vida nas primeiras décadas do século XVII. É o caso de Itinga e da Cidade Nova. As características da cidade nascente apontam para uma população em geral pobre, vivendo da pesca, do plantio e da pecuária, em parte dispersa no entorno da cidade, e dotada de um mínimo de organização religiosa, político-administrativa e militar. Contudo, como saber se essa descrição corresponde de fato à realidade da cidade do Natal à época?

\section{A interpretação da cidade}

Acreditamos que um olhar crítico, interpretativo, sobre essas representações pode certamente nos ensinar algo sobre as primeiras décadas de vida da cidade do Natal, objeto da presente análise. Como dissemos, além de ver, é preciso interrogar os mapas. Para isso, vamos a partir de agora recorrer a fontes manuscritas coevas a fim de confirmar, reforçar ou nuançar o que nos dizem os mapas, embora, obviamente, nunca possamos estar totalmente seguros de sua validade. Inevitavelmente, temos que transcrever essas fontes, a partir das quais o confronto com os mapas será empreendido. Sublinhamos os trechos mais importantes para as nossas considerações.

Os náufragos da nau Santiago, que estiveram em Natal em 1602, deixaram o seguinte registro:

Neste Rio Grande, que dista da Paraíba quarenta léguas, se viu esta peregrina gente em aperto, por falta de mantimentos, que não havia, nem os soldados que ali residiam naquele Rio, os tinham para lhos darem, antes padeciam necessidade. Acharam na nova cidade de Santiago, que ali se principia, e tem já três casas de pedra e cal, a D. Beatriz de Menezes, mulher do capitão dali, João Rodrigues Colaço, que naquele dia era ausente, e ela os agasalhou e proveu 
com grande caridade o que foi possível [...] por aldeias deste Rio, e nova cidade andavam na conversão do gentio dois padres da Companhia de Jesus [...] (BRITO, 1905, p. 60-61). ${ }^{18}$

Diogo de Menezes, Governador Geral do Brasil, escrevendo em 4 de dezembro de 1608 ao Rei Filipe, III da Espanha e II de Portugal, ao descrever a situação de precariedade das Fortalezas da Paraíba e do Rio Grande e o que mandou fazer para restaurá-las, acrescenta que

[...] na carta de 18 de junho me manda Vossa Majestade que não haja no Rio Grande mais do que trinta soldados e quatro bombardeiros, um capitão, um alferes, um sargento e na Paraíba vinte com os mesmos oficiais e assim o tenho provido e mandado, mas parecia-me lembrar a Vossa Majestade que no que toca à Fortaleza do Rio Grande pelo menos que há mister de soldados, são cinquenta porque está mui distante de onde se lhe possa acudir a povoação, que está feita e não tem gente e o posto é mui importante e nas praças da milícia ordinário é haver faltas e para haver trinta soldados é necessário haver quarenta praças (MENEZES, 2004).

Outro documento não datado, assim descreve Natal:

[...] tem uma Fortaleza, posto que não de todo acabada, meia légua dela está uma povoação de obra de vinte e cinco ou trinta moradores ou vizinhos [...] de criadores de gados e mantimentos que cultivam e pescaria [...] na Fortaleza há nove peças de artilharia de bronze e dezenove de ferro [...] é bastantemente servida de armas e muniçóes [...] há um vigário que tem cura das almas e tem de ordenado cada ano 200 mil réis, importam as ordinárias da igreja 40 mil cada ano (ANÔNIMO, [s.d.]) $)^{19}$.

Num texto muito semelhante ao anterior, no qual se inspirou ou para o qual serviu de inspiração, datado de 1612, Diogo Campos Moreno disse o seguinte a respeito de Natal:

Tem mais uma povoação, a meia légua da Fortaleza pelo rio acima [...] a qual tem pobremente acomodados até 25 moradores brancos, fora da obrigação da Fortaleza, e destes têm pelas roças e redes e fazendas principais da capitania até oitenta moradores, os quais pediram modo de governança e se lhes concedeu o ano de seiscentos e onze, pelo governador D. Diogo e Menezes, o qual com parecer da Relação elegeu o juiz, um vereador e escrivão da Câmara, procurador do Conselho e procuradores de índios [...] o ano de seiscentos e onze se

\footnotetext{
${ }^{18}$ É mais um nome distinto para Natal, curiosamente semelhante ao da nau. Eles também elogiam o trabalho dos missionários jesuítas nas aldeias.

${ }^{19}$ A citação se encontra no capítulo intitulado "relação copiosa das capitanias, povoaçôes de portugueses e outras muitas coisas das terras de Santa Cruz", às folhas $132 \mathrm{v}$ e 133 . A mesma fonte lista o corpo militar da fortificação, com seus respectivos ordenados. Essa citação, com pouquíssimas variaçóes, também se encontra em outra fonte citada por LYRA, 2008, p. 54-55.
} 
demarcou, por ordem do dito Senhor esta capitania (SLUITER, 1949, p. 559-560 e LYRA, 2008, p. 52). ${ }^{20}$

O Auto de Repartição de Terras do Rio Grande, datado de 1614, traz a referência documental mais antiga conhecida sobre a igreja matriz de Natal:

Pero Vaz Pinto escrivão da fazenda, alfândega e almoxarifado desta Capitania do Rio Grande por sua Majestade etc. Certifico que eu trasladei duas cópias do bando atrás do senhor governador e capitão geral deste estado do Brasil Gaspar de Souza das quais preguei uma nas paredes da igreja matriz desta dita capitania por não ter portas e outra nas da Fortaleza desta dita capitania, para assim vir a notícias de todos em verdade do que passei a presente por mim assinada em vinte de fevereiro de seiscentos e quatorze. Pero Vaz Pinto (ANÔNIMO, 1909, p. 118).

O Diálogo das Grandezas do Brasil, obra atribuída a Ambrósio Fernandes Brandão e compilada em 1618, apesar de náo citar nem descrever a cidade do Natal, nos fornece indiretamente alguma pista tanto sobre o motivo da fundação da cidade como sobre o uso que se fazia da terra:

A capitania do Rio Grande, que foi povoada e fortificada, por mandado de Sua Majestade, por Manuel Mascarenhas Homem, capitão que era de Pernambuco, e por Feliciano Coelho de Carvalho, capitão que era da Paraíba, no ano de 1597, está situada a seis graus da parte do Sul, tem na boca da barra uma fortaleza muito bem provida, assim de soldados pagados da fazenda de Sua Majestade, como de artilharia, com a qual se defende a entrada dos piratas franceses naquele porto, onde costumavam a ir espalmar as suas naus, e a prover-se de água e mantimentos, e ainda a carregar de pau Brasil, que compravam ao gentio da terra a troco de resgate. Assiste nesta capitania um capitão de Sua Majestade a qual se provê de três em três anos. Não há nela engenhos de fazer açúcares mais de um até este ano de 1618, por a terra ser mais disposta para pastos de gado, dos quais abunda em muita quantidade até entrar na capitania da Paraíba que lhe está conjunta (BRANDÃO, 2005, p. 33).

Frei Vicente do Salvador, escrevendo em 1627, diz o seguinte, referindo-se à fundação de Natal:

Feitas as pazes com os Potiguares, como fica dito, se começou logo a fazer uma povoação no Rio Grande uma légua do forte, a que chamam a Cidade dos Reis, a qual governa também o capitão do forte, que El-Rei costuma mandar cada três anos. Cria-se na terra muito gado

\footnotetext{
${ }^{20}$ O Senado da Câmara, organizado em 1611, segundo este testemunho, já existia desde janeiro de 1605, pelo menos. Os limites da capitania, segundo o relato, foram igualmente definidos em 1611.
} 
vacum, e de todas as sortes, por serem para isto as terras melhores que para engenhos de açúcar [...] (DO SALVADOR, 1885-1886, p. 158).

O capitão-mor Domingos da Beiga também descreveu a capitania, a Fortaleza dos Reis Magos e a cidade do Natal, por volta de 1630. Dela transcrevemos as seguintes passagens:

$\underline{\text { É este rio [Potengi] o mais fértil de peixe que há na Bahia, digo no Brasil, e nele se faz muitas }}$ e grandes pescarias. $\mathrm{E}$ as mesmas pelas costas no verão de que vai muito peixe salgado à Paraíba e a Pernambuco. A Fortaleza do Rio Grande é a maior e mais bem traçada que há no estado do Brasil [...] há nesta Fortaleza oitenta praças [...] um quarto de légua da Fortaleza está a povoação que chamam cidade do Natal. Tem uma boa igreja, porém a povoação é muito limitada respeito dos moradores estarem e morarem em suas fazendas onde têm muito deles suas casas mui nobres. $\mathrm{Na}$ cidade assiste um juiz ordinário e um ouvidor e os mais dos oficiais da Câmara. Haverá em toda esta capitania até trezentos moradores e os mais deles com sua família e escravos e seus currais de gado [...] tem muitos currais de gado nesta capitania. Há nelas dois engenhos de açúcar [...] desta gente se fazem duas companhias de ordenança com seus capitães oficiais são destros em suas armas porque os mais deles foram soldados na Fortaleza e uma esquadra de até quarenta homens a cavalo. Do gentio da terra haverá pouco mais de 300 flecheiros repartidos em quatro aldeotas [...] havia aqui tanta quantidade deles que lhe não sabia o número e ainda estes a cada dia vão fugindo para o Ceará pelo ruim trato que aqui lhe fazem os capitães [...] (LYRA, 2008, p. 57-59).

O holandês Adriano Verdonck, que visitou Natal em 1630, nos deixou também suas impressóes sobre a cidade. Delas, é possível concluir que [...]

A cidade contava com 35 a 40 casas de palha e barro. Os habitantes mais abastados viviam habitualmente nas suas fazendas e vinham apenas nos domingos e dias santificados ouvir missa. Nesse raio de seis a nove milhas não residiam mais de 120 a 130 campônios na sua maioria rústicos. Dois eram os engenhos existentes: um no Ferreiro Torto [...] e outro na Várzea do Cunhaú, a 19 milhas ao sul de Natal [...] (apud LYRA, 2008, p. 75).

Barléu, historiador do Brasil holandês, em seu livro escrito em latim e publicado em 1647, diz o seguinte a respeito de Natal:

Depois desta vem a província do Rio Grande com quatro freguesias. Fica aí a vila de Natal, de aspecto triste e acabrunhador pelas suas ruínas, vestígios da guerra. Deu-se permissão aos moradores de edificar nova cidade, em lugar mais feraz e em sítio mais vantajoso, na freguesia de Potengi. A légua e meia de Natal vê-se o forte de Ceulen (BARLÉU, 1974, p. 128). 
Vamos, a partir de agora, confrontar as informaçôes contidas nesses documentos manuscritos com a descriçáo que fizemos de Natal e seu entorno baseada exclusivamente nos mapas, no intuito de verificar até que ponto essa representaçấo corresponde de fato à realidade, mesmo reconhecendo sempre os limites desse esforço. Para facilitar a análise, dividimos em trechos a descrição que fizemos da cidade, como se segue:

\section{1) Natal: uma cidade fundada a certa distância da Fortaleza dos Reis Magos}

Frei Vicente do Salvador, Diogo de Campos Moreno, Diogo da Beiga e um autor desconhecido confirmaram essa informação cartográfica, embora as distâncias mudem de um quarto a uma légua entre os diferentes relatos. A distância mais frequente, tal qual aparece aqui e em documentos posteriores, é meia légua, cerca de 3 quilômetros, o que condiz perfeitamente, aliás, com a distância atual em linha reta da Fortaleza dos Reis Magos à Praça André de Albuquerque, o marco zero da cidade. Essa distância entre os primeiros núcleos urbanos litorâneos recuados em relação ao mar e suas fortificaçôes à beira-mar era, aliás, uma das estratégias de defesa contra os ataques provenientes do mar.

\section{2) A regularidade $x$ a irregularidade do núcleo urbano}

Este é certamente um dos pontos mais obscuros. Ainda que as Figuras 5 e 6 (1640) indiquem visivelmente um espaço central regular, livre de construçôes, as três Figuras anteriores analisadas não confirmam essa informação, embora as cinco Figuras em questão apontem claramente para algum espaço central, destituído de construçóes.

Alguns historiadores clássicos de Natal afirmam que o sítio da cidade foi demarcado no ato de sua fundaçáo. Rocha Pombo, por exemplo, menciona que, após escolhido o sítio da cidade, em lugar elevado, à margem direita do Rio Potengi, "ali demarcou Jerônimo o perímetro urbano, onde se começou logo a construir uma pequena igreja para servir de matriz" (POMBO, 1921, p. 47). Câmara Cascudo também menciona que cruzeiros foram utilizados para demarcar a área urbana da cidade (CASCUDO, 1999, p. 52). Mesmo que náo citem qualquer fonte que fundamente essa ação, é muito provável que isso tenha ocorrido. Contudo, tal demarcação significou, porventura, algum "plano urbanístico" inicial, regular, para a cidade?

$\mathrm{Na}$ ausência de uma documentação comprobatória, o máximo que podemos fazer é especular sobre o assunto. A esse respeito, e em trabalho anterior (TEIXEIRA, 2009, p. 235236), discorremos sobre alguns indícios que podem indicar a regularidade, senáo da cidade como um todo, pelo menos de sua praça central, a atual Praça André de Albuquerque. Entre outros argumentos apresentados, está o de que Natal já surgiu com o título de cidade (TEIXEIRA, 2019) e, por mais precária que fosse, deve ter recebido, em razão desse status, alguma atenção quanto a um desenho urbano regular, pelo menos em sua praça central. Assim, mesmo que essa questão continue em aberto, tendemos a acreditar que não somente o sítio urbano da cidade foi demarcado, mas que foi imposto um formato regular para a sua praça central, que surgiu juntamente com a cidade, como parecem demonstrar alguns mapas. 


\section{3) Casario urbano em geral esparso e humilde}

Essa informação é inteiramente comprovada pelas fontes manuscritas coevas. A cidade, que então se construía, tinha apenas três casas de pedra (náufragos do Santiago, 1602); sequer tinha gente em 1608 (Diogo de Menezes); havia apenas de 25 a 30 moradores brancos ou vizinhos em 1612 (Diogo de Campos Moreno e fonte sem autoria conhecida); as casas eram de palha e barro (Adriano Verdonck, 1630); era muito limitada (Domingos da Beiga, c. 1630); de aspecto triste e acabrunhador (Barléu, 1647).

A afirmação do governador geral do Brasil, Diogo de Menezes, de 1609, para quem a cidade "não tem gente", mesmo sendo um exagero, evidencia a realidade de uma urbe pouquíssimo povoada e de poucas habitaçôes. De fato, Natal tinha uma população muito pequena, como era de se esperar. Embasados em um estudo anterior, no qual analisamos o Auto de Repartição de Terras do Rio Grande, um importante documento datado de 1614, também pudemos extrair algumas informaçóes a esse respeito:

[...] Natal tinha, em 1614, pelo menos 16 casas [...] considerando um número mínimo de cinco moradores por casa, teríamos, entáo, pelo menos 80 moradores na cidade, em 1614, mas era um número provavelmente superior. As 35 ou 40 casas estimadas por Adriano Verdonck 16 anos depois, em 1630, daria uma populaçáo na cidade entre 175 e 200 habitantes, usando a mesma estimativa por casa; 3) na Fortaleza, viviam mais de 80 soldados, número que chegou a ser bem superior alguns anos antes, quando da conquista da terra contra os franceses; [...] (TEIXEIRA, 2014, p. 119).

Quanto à fragilidade dessas habitaçóes, ela aparece de certa forma na constatação dos náufragos do Santiago, em 1602, ao destacar justamente o contrário, isto é, que havia três casas de pedra na cidade que entáo se construía. Deveria ser uma exceção tal que mereceu destaque. $\mathrm{O}$ mesmo Auto de Repartição também nos fornece alguma indicação sobre a precariedade das casas:

[...] eram de palha (datas 4 e 135); tinham telhas (4 e 169); encontramos uma interessante referência a umas "casas de terra de sobrado", ou seja, de taipa e em mais de um pavimento (data 59); a dimensão do lote certamente previa espaço para o quintal, como nas casas da data 136. Na data 35, são mencionadas casas no sítio da cidade doadas por João Roiz (Rodrigo) Colaço a Pero da Costa, que "caíram com o tempo haverá cinco anos". Na data de n ${ }^{\circ} 45$, doada em 12 de janeiro de 1603, havia casas que "[...] caíram haverá dois anos e náo se levantaram mais" (TEIXEIRA, 2014, p. 116)

\footnotetext{
${ }^{21}$ Os dados em parênteses se referem ao número das "datas de terras" concedidas nos "chãos da cidade", ou seja, concessóes de lotes pelo Senado da Câmara, mediante pagamento de foro anual, para a construçáo de casas pelos moradores.
} 
Barléu, historiador do Brasil holandês, continua a insistir na precariedade da cidade e, por conseguinte, de seu casario, que ele não menciona diretamente. Sua constatação se insere num contexto agravador, o da guerra de conquista pelos holandeses, como ele mesmo destaca. Não é preciso muita reflexão para concluir que, considerando a quantidade de casas no espaço da cidade nascente, essas habitaçóes estavam necessariamente dispersas no território, seja no entorno da praça central, seja em direção ao Rio Potengi, por razôes das atividades dos seus moradores, como veremos a seguir.

4) Casas e outras edificaçôes no entorno da cidade; a criação de gado e a exploração da pesca

O documento de autoria desconhecida, assim como os relatos de Diogo de Campos Moreno, Frei Vicente do Salvador, Ambrósio Fernandes Brandão, do capitão-mor Domingos da Beiga e do holandês Adriando Verdonck, transcritos acima, afirmam a existência de fazendas nas proximidades e/ou de atividades agropecuárias realizadas no entorno, como a criação de gado e/ou a pesca. O Auto de Repartição de Terras, de 1614, também confirma de modo contundente tais atividades, além de outras como a exploraçáo do sal e a agricultura de subsistência, assim como a existência dessas edificaçóes rurais. Numa população profundamente ligada às atividades rurais, não é difícil compreender por que as sedes de fazenda eram de melhor qualidade quando comparadas às casas urbanas, como notaram Domingos da Beiga e Adriando Verdonck. Os moradores passavam mais tempo no campo do que na cidade.

No "Livro que dá Razáo ao Estado do Brasil", o seu autor, Diogo de Campos Moreno parece resumir essas consideraçôes:

Tem algum pau brasil fino mas mui raro a respeito de lhe arrancarem os franceses até as raízes quando ali continuavam, tem jacarandá mais delgado do que o da Bahia, tem pau amarelo para tintas e outras madeiras para obras de toda sorte de embarcaçóes ou casas. Todo gênero de criação multiplica muito, e nos matos há muita casa, e em toda a costa grandes pescarias, e muito âmbar (SLUITER, 1949, p. 562).

\section{5) Edificaçôes oficiais dentro da cidade e no seu entorno}

Dentre os manuscritos transcritos, apenas o Auto de Repartição de Terras, de 1614, menciona a igreja matriz, sem portas. É a primeira referência escrita que conhecemos sobre esse edifício em Natal. Indiretamente, outros relatos deixam claro a sua existência, como o de Adriano Verdonck, quando cita o hábito dos moradores do entorno se dirigirem à cidade para as missas e dias santos, ou o documento não datado, que menciona o salário do vigário da cidade. Ademais, a igreja é facilmente identificada na cartografia analisada, tanto no interior quanto no entorno da cidade, e é muito difícil supor que ela não tenha sido construída, ainda que fosse muito rudimentar, no ato mesmo de fundação da urbe. A sua menção era, talvez, uma informação por demais evidente para ser registrada nos relatos escritos. 
É mais difícil, contudo, afirmar categoricamente a existência da casa de câmara e cadeia, braço secular do poder instituído, desde a fundação da cidade considerando que não há, objetivamente, uma comprovação documental definitiva, gráfica ou manuscrita, a esse respeito. Alguns mapas, como vimos, podem dar a entender a sua presença, mas não há como afirmar com certeza. A primeira referência manuscrita explícita conhecida de sua existência data de 1674 (TEIXEIRA, 2012, p. 93). O Auto de Repartição de Terras do Rio Grande indica que o Senado da Câmara já existia em janeiro de 1605 (TEIXEIRA, 2014, p. 115), fato fundamental para a sua construção. Essa edificação pode remontar, contudo, à fundação da capital potiguar em 1599, pois vários indícios levam a crer que ela foi fundada com o título de cidade, o que exigia a construção desse edifício no ato da fundação ou nos anos subsequentes.

Quanto ao entorno, destaca-se a Fortaleza dos Reis Magos, tanto nas referências gráficas quanto escritas, pois se tratava efetivamente do edifício mais importante. Outras edificaçôes oficiais representadas no entorno, porém, não são confirmadas nos manuscritos analisados. A casa do tenente e o cruzeiro, na Figura 2 (1609), só é citada no texto que a acompanha.

Alguns mapas indicam uma edificação entre a cidade e a fortificação. Deve ter sido a mesma que pertenceu a Mathias van Ceulen, comandante das tropas holandesas que conquistaram a capitania, como vimos. Joannes de Laet, ao relatar a chegada de parte das tropas batavas por terra, indica que perto da "pequena cidade" do Natal, havia uma casa situada numa colina (LAET, 1912, p. 343). A Figura 7 (1665) identifica uma igreja, talvez uma simples capela, chamada de Nossa Senhora dos Montes, também entre a cidade e a Fortaleza dos Reis Magos, mas os manuscritos não fazem qualquer referência a esse templo católico, que deve ter existido. Talvez se localizasse no atual bairro da Ribeira ${ }^{22}$.

A Fortaleza dos Reis Magos é de longe o edifício oficial mais citado e representado nas fontes documentais, gráficas ou escritas. Fundada com uma clara função militar de conquista territorial, o surgimento da cidade se confunde com o de sua fortaleza, situada no seu entorno. A esse respeito, gostaríamos de nos ater a um único relato - pouquíssimo explorado na historiografia do Rio Grande do Norte ${ }^{23}$ - do inglês Anthony Knivet, que esteve no Rio Grande em 1601 ou 1602, primeiramente porque confirma outros relatos semelhantes ocorridos antes mesmo da fundação de Natal e demonstra, assim, o caráter eminentemente militar da empreitada colonial inicial no Rio Grande, ${ }^{24}$ embora ele se refira exclusivamente aos inimigos índios, que não arrefeceram sua animosidade mesmo após os acordos de paz

\footnotetext{
${ }^{22} \mathrm{O}$ fragmento de um mapa publicado em 1779, intitulado View of the coast of Brazil before Rio Grande (Vista da costa do Brasil diante do Rio Grande) mostra o perfil do litoral em torno de Natal. Entre outras informaçôes fornecidas, indica uma igreja à esquerda da Fortaleza. Seria a mesma igreja dos mapas seiscentistas? Ver TEIXEIRA, 2018.

${ }^{23}$ Por exemplo, na historiografia em geral não há conhecimento de que os líderes militares citados e que vieram "pacificar" os índios, de praxe com o uso da força bruta, na verdade retornaram à capitania, pois são os mesmos que vieram ao Rio Grande em dezembro de 1597 construir a fortificação e dar início à povoação. ${ }^{24}$ Ver, a esse respeito, DO SALVADOR, 1885-1886, p. 152-153.
} 
que assinaram com os portugueses, em 11 de junho de 1599, fato primordial para a fundaçáo de Natal, em 25 de dezembro do mesmo ano. O relato também serve indiretamente como uma das explicaçóes para a precariedade da cidade, como temos visto até aqui, uma vez que ela surge em tempos muito belicosos. Mas, o mais importante para este trabalho, é o fato de Anthony Knivet fazer menção não somente a uma, mas a duas fortificações perto da cidade. É o único cronista a fornecer tal informaçâo. Apesar de visivelmente fantasioso e exagerado em alguns momentos, a essência do relato tem amplas razóes para ser crível como um fato histórico.

Passados vinte dias que estávamos na cidade [Pernambuco], Feliciano Coelho [capitão-mor da Paraíba] mandou avisar a Mascarenhas Homem [capitão-mor de Pernambuco] que ele estava cercado no Rio Grande pelos Potiguaras, e que se não fosse socorrido por ele, ele seria obrigado a perder a Cidade dos Reis, com a perda de suas vidas. Mascarenhas então decidiu ir pessoalmente, deixando a cidade de Pernambuco sob a direção de meu mestre Salvador Correia de Sá; e assim partimos de Pernambuco com quatrocentos portugueses e três mil índios, e em sete dias chegamos ao Rio Grande sofrendo escaramuças de diversos canibais ao longo do caminho. Assim que chegamos diante da cidade o nosso capitáo fez um longo discurso para os portugueses e para os índios encorajando-os contra os infiéis cujo exército era de pelo menos quarenta mil homens, e desejou que todos se confessassem ao Pai Celestial e fizessem a comunhão, porque na manhá seguinte ele estava determinado a atacar os seus inimigos, o que foi muito bem executado, porque os canibais, no dia anterior, tinham feito duzentos prisioneiros numa escaramuça e matado muitos deles para devorá-los, e não esperavam a nossa chegada no auge de suas festanças e bebedeiras, de modo que demos sobre eles. Os habitantes da cidade, no outro lado, ouvindo o barulho, atacaram, pegando-os subitamente de surpresa. Fizemos uma matança tão grande entre eles, que levantaram o cerco, com a perda de três mil prisioneiros e cinco mil mortos. O Rei desses canibais se chamava Piraiuwath, que significa barbatana de peixe. Quando esse príncipe pagão se viu vencido por um número tão pequeno como o nosso em comparação com as suas multidóes, ele enviou alguns de seus homens para tratar de paz com Manuel Mascarenhas, com a condição de que se ele libertasse todos os prisioneiros e que ele e os de sua naçáo vivessem como homens livres, então ele e todos os seus se submeteriam como súditos dele e que seriam batizados, o que foi aceito por Mascarenhas Homem. Assim, uma das maiores províncias de todo o norte do Brasil se tornou súdita do Rei da Espanha. Feita a conquista, o capitáo-mor construiu dois possantes fortes perto da cidade, à margem do rio, e solicitou de Pernambuco quarenta peças de ferro fundido, colocando vinte em cada forte. Muitos soldados ganharam com essa conquista muitas pedras preciosas, diamantes, rubis e uma grande quantidade de safiras azuis, em algumas aldeias que se localizam perto do mar. Encontramos âmbar-gris em grande quantidade, que os indígenas chamam Pirapoun Arepoty. Aqui a sorte me foi favorável, porque ganhei mais de quinhentos 
crownies nessa jornada. Depois dessa conquista, Mascarenhas Homem retornou a Pernambuco (KNIVET, 1906, p. 241-243) 25 .

Se houve, de fato, duas fortificaçóes à margem do rio, o que provavelmente nunca saberemos de fato, então uma delas deixou de existir há muito tempo. Na Figura 7 (1665) há uma edificação na margem esquerda do Rio Potengi, na sua foz, de fronte à Fortaleza dos Reis Magos, mas não parece representar uma fortificação. Há, de fato, registros de que um fortim foi efetivamente erigido na margem esquerda da foz do Rio Potengi, mais ou menos no lugar da edificação da Figura 7, mas somente no início do século XIX (TEIXEIRA, 2009, p. 426).

\section{6) Novos assentamentos urbanos no entorno, como Itinga e a Cidade Nova}

A documentação manuscrita do período da ocupação holandesa do Rio Grande (16331654) confirma vigorosamente a existência de uma Cidade Nova, como aparece na Figura 7 (1665). Além dos escritos do historiador Barléu, que transcrevemos acima, cartas e despachos lavrados por outras autoridades da mesma nacionalidade evidenciam providências efetivamente tomadas para a construção dessa nova cidade, em substituição a Natal. Ela ficaria na confluência do Rio Potengi com o Jundiaí (MOURA, 1986, p. 106-107) ${ }^{26}$. Johan Neuhof, por exemplo, se refere a essa nova cidade - denominada de Amsterdam - assim como a Natal, nos seguintes termos:

Acima do Rio, há uma cidade denominada Amsterdam. Seus habitantes vivem da pesca, da produção de farinha e do plantio de fumo [...] perto da aldeia de Natal e do Forte dos Reis Magos passa um rio conhecido por rio da cruz que nasce de um pequeno lago no Rio Grande (NEUHOF apud MOURA, 1986, p. 107).

A ideia de se fundar uma "nova cidade", mencionada por Barléu, resulta da precariedade de Natal, situação agravada certamente com a conquista da capitania pelos batavos, que inclusive levou ao abandono da cidade por parte dos seus poucos moradores. Entretanto, para além dessas referências documentais holandesas, não temos conhecimento de qualquer outra fonte ou vestígio, por exemplo, arqueológico, que confirme que essa cidade nova realmente existiu. Deve ter sido algo efêmero. A rigor, teria sido o único período em toda a história da cidade em que ela perdeu o seu status de capital. Quanto à povoação de Itinga, ela corresponde, hoje, à povoação Utinga, no município de São Gonçalo do Amarante.

\footnotetext{
${ }^{25}$ Mantivemos a grafia para os nomes indígenas citados tal qual encontrada no documento original, escrito em inglês. A referência ao Rei da Espanha se deve à união das coroas ibéricas. A existência, pelo menos do âmbar, é confirmada por Diogo de Campos Moreno, em citaçáo anterior neste trabalho.

${ }^{26}$ Pedro Moura, baseando-se em outros autores, como Hélio Galvão, cita vários documentos holandeses que apontam efetivamente para a existência dessa cidade nova, inclusive a citaçáo do próprio Barléu.
} 


\section{7) Os aspectos sociais da cidade}

As fontes textuais analisadas confirmam e reforçam as características socioeconômicas fundamentais da sociedade que se forjava então, de alguma maneira perceptíveis nos mapas. A própria configuração físico-espacial e características edilícias da urbe nascente revelam determinados aspectos socioeconômicos essenciais. Era, de fato, uma sociedade pobre, extremamente ligada à terra por meio de suas atividades agropecuárias e da pesca; alguns, de melhor condição, viviam nas fazendas do entorno e possuíam escravos; a sociedade, como era de se esperar, era extremamente religiosa, se organizava administrativamente por meio do poder municipal e dava natural importância a questôes de ordem militar, aspecto que se sobressai visivelmente dentre as preocupaçôes da época, num mundo marcado por inimigos índios e estrangeiros.

\section{Considerações finais}

O desenho, em particular a cartografia histórica, como qualquer tipo de registro documental, tem suas limitaçôes, lacunas, às vezes incongruências, algo que se confirma plenamente nessa análise, especialmente em se tratando de uma cidade que foi representada de forma extremamente sumária e com alto grau de simbolismo. As limitaçôes e lacunas se evidenciam, por exemplo, no que tange à organização ou configuração urbana inicial de Natal. Até mesmo o formato regular da praça central é uma suposição, ainda que plausível, pois nem a cartografia disponível nem os relatos por escrito dos que viveram os primeiros anos da cidade dão pistas seguras ao seu respeito.

Semelhantemente, as edificações não são identificadas de modo claro; é possível perceber a existência de uma igreja no interior da cidade, por exemplo, na Figuras 5 (1640) e 6 (1640), mas a representação da casa de câmara e cadeia é provável, porém não conclusiva. $\mathrm{O}$ documento escrito mais antigo de que temos conhecimento sobre a casa de câmara e cadeia da cidade data de 1674, como vimos. Estamos convictos da existência de ambas as edificaçôes desde o primeiro ou primeiros anos de vida de Natal, mas nos baseamos para isso em outros dados e circunstâncias. Por exemplo, o simples fato de a casa de câmara e cadeia estar em ruínas em 1674, juntamente com um conjunto de outras evidências, nos leva a inferir que esta edificação deve ter sido edificada no ato ou logo após a fundação de Natal. Afinal, uma vida útil de cerca de 70 anos é plausível para uma edificação que, embora importante, certamente foi construída com materiais precários e não deve ter contado com um trabalho frequente de manutençãa ${ }^{27}$.

Outra lacuna diz respeito à topografia do sítio urbano de Natal. Localizada em ponto elevado e recuado em relaçáo ao rio e ao mar, por razóes principalmente de defesa, mas su-

\footnotetext{
${ }^{27}$ Vimos essas condiçôes plenamente no estudo que fizemos sobre as casas de câmara e cadeia do Rio Grande do Norte. Ver TEIXEIRA, 2012.
} 
ficientemente próxima do mar como meio de comunicação com a metrópole e mais ainda do rio como fonte de água potável, a cidade do Natal obedecia assim a três características comuns às primeiras cidades litorâneas do Brasil colonial. Se as representaçôes cartográficas apresentam-na recuada em relação ao mar e um pouco menos em relação ao rio, deixam de lado, porém, a topografia elevada do sítio. A cidade e seu entorno são representados como se estivessem em terreno plano, ao nível do mar. As Figuras 4 (1633), 5 (1640) e 6 (1640) mostram certo relevo, mas visivelmente de forma idealizada, fora da cidade. $\mathrm{O}$ texto que acompanha a Figura 2 (1609) menciona e indica "padastros" ou dunas no entorno da cidade e a Figura 4 (1633), assim como a Figura do livro de Joannes Laet, muito próxima da anterior, não reproduzida aqui, representam algumas dessas dunas, mas o núcleo urbano em si se localiza na mesma "cota topográfica", poderíamos dizer, da Fortaleza dos Reis Magos ou do Rio Potengi, o que náo corresponde à realidade, como ainda é possível perceber atualmente ${ }^{28}$. Será preciso esperar o século XIX para que a cartografia demonstre as diferenças de nível topográfico entre a cidade alta e a cidade baixa - a Ribeira.

Quanto às incongruências, vimos que mapas diferentes mostram a cidade com características diferentes. As Figuras 5 (1640) e 6 (1640), e especialmente esta última, demonstram uma Natal bem mais consolidada, adensada, do que as demais, certamente mais realistas por apresentarem-na mais precária. Outra incongruência, fruto provavelmente do desconhecimento geográfico, são algumas representaçôes como as do Rio Potengi, novamente nas Figuras 5 (1640) e 6 (1640), mas também na Figura 2 (1609). O rio e sua foz aparecem num formato muito retilíneo, quase um canal, bastante diferente, portanto, do que ele é de fato.

Há informaçôes aparentemente desencontradas no que tange ao riacho que parece nascer num lago e desembocar no Rio Potengi, mas que são dissipadas numa análise mais cuidadosa. Na Figura 4 (1633), ele está ao norte da cidade, entre esta e a fortaleza; na Figura 7 (1665), aparece um riacho ao sul de Natal, que também é atravessado por um caminho e que também parece nascer numa lagoa, chamada de Tiuru. Acreditamos que as duas Figuras não estão mostrando o mesmo riacho nem a mesma lagoa, pois tudo indica que o núcleo urbano inicial da cidade, que se situava (e se situa) em terreno elevado, estava de certa forma delimitado por dois riachos, um ao norte, outro ao sul, ambos nascendo em lagoas distintas e desaguando no Rio Potengi. Johan Neuhof se referiu ao riacho e lagoa ao norte da cidade, ao afirmar, como vimos, que "perto da aldeia de Natal e do forte dos Reis Magos passa um rio conhecido por rio da cruz, que nasce de um pequeno lago no Rio Grande". É o que se apresenta na Figura 4. Na estampa de Joannes de Laet, à qual nos referimos sem reproduzi-la aqui, esse riacho também se apresenta na mesma situação e recebe a mesma denominação.

Quanto ao riacho ao sul da cidade de então, bem como a sua nascente na lagoa Tiuru (Figura 7) ambos são, em termos locacionais, muito coerentes com vestígios atuais da cidade.

\footnotetext{
${ }^{28}$ As três características citadas ainda podem ser percebidas considerando o núcleo urbano inicial de Natal na área urbana da cidade atual, em torno do marco zero (Figura 1), inclusive quanto à elevação do sítio inicial.
} 
A lagoa pode muito bem ser a atual lagoa Manuel Felipe e o riacho foi fonte de água para a populaçáo de Natal. Para ele se dirigiam os moradores da cidade tomando o "caminho de beber", origem da atual Rua Santo Antônio. O riacho é atualmente o canal do Baldo. Esse riacho ficava mais perto da cidade do que o riacho do norte, e deve ter sido mais utilizado como fonte de água potável. Aparentemente, o historiador Olavo de Medeiros Filho teve alguma hesitação em relação a essa questão, pois associou o riacho e a lagoa da Figura 4 ao riacho ao sul da cidade e à lagoa Manuel Felipe (MEDEIROS FILHO, 1991, p. 65) - o que não poderia ser porque aqueles se situavam ao norte e estes ao sul da cidade. Em outro trabalho, ele concluiu corretamente - pois desta feita é coerente com a Figura 4 (1633) - que esse mesmo "rio da cruz", era um riacho localizado ao norte de Natal, não mais existente. Nascia na lagoa do Jacó e cortava "os trechos finais das avenidas Januário Cicco e Engenheiro Hildebrando de Góis, no bairro das Rocas” (MEDEIROS FILHO, 2007, p. 34). É certo que havia uma área alagadiça situada ao norte de Natal, em direção à fortaleza. Sobre essa área o capitão-mor João de Barros Braga mandou construir, em 1733 ou 1734, uma ponte de mais de 60 braças, ou 132 metros ao norte da cidade (TEIXEIRA, 2009, p. 241) ${ }^{29}$, demonstrando, aliás, que o eixo de crescimento urbano demandava o bairro da Ribeira, ao norte, em direção à Fortaleza dos Reis Magos, desde pelo menos o século XVIII. Um mapa de Natal, publicado em 1868 (MENDES, 1868, p. 43), bastante conhecido, mostra claramente essa área alagadiça entre os dois bairros mais antigos de Natal, a Cidade Alta, onde ela se iniciou, e a Ribeira. Contudo, não podemos afirmar com certeza se essa área alagadiça corresponde ao riacho e à lagoa da Figura 4.

A ponte que aparece na Figura 4 (1633) provavelmente é a mesma citada na data de terra de n 67, registrada no Auto de Repartição de Terras do Rio Grande, de 1614:

[...] deu Jerônimo de Albuquerque a Manoel Roiz em doze de abril de seiscentos e quatro, são duzentas braças de largo e de comprido desde o riacho da ponte até os cháos das casas de Joáo Rodrigues Colaço sempre ao longo do rio Potigi, está feito nele uma casa (TEIXEIRA, 2014, p. 117).

Até prova em contrário, é plausível inferir que se trata da mesma ponte - tendo em vista a relativa proximidade das datas no relato de 1614 e no mapa de 1633 - e do mesmo riacho da cruz, citado por Neuhof e representado, com o mesmo nome, no mapa de Joannes de Laet.

Finalmente, há algumas incongruências, não necessariamente erros, entre as fontes cartográficas e as fontes manuscritas, com informaçóes que não se confirmam mutuamente. Desconhecemos algum mapa que comprove a existência das duas fortificaçóes citadas por Anthony Knivet, nem fonte manuscrita conhecida atestando a existência de uma igreja num local rural, a meio caminho entre a cidade e a Fortaleza dos Reis Magos, como aparece em

\footnotetext{
${ }^{29}$ Uma braça correspondia a $2,2 \mathrm{~m}$.
} 
alguns mapas analisados. Essas incongruências não são, porém, suficientes para desconsiderar a priori essas informaçóes, especialmente no caso da igreja. A Figura 2 (1609) parece prenunciar a sua existência, ao representar um cruzeiro também entre a cidade e a fortaleza, perto da "casa do tenente". Teria recebido o riacho este nome em funçáo desse cruzeiro?

Apesar de algumas ressalvas, fica bastante evidenciado que não é possível simplesmente descartar as fontes cartográficas, particularmente no que se refere à representação da cidade do Natal, como sendo mero simbolismo desprovido de maior veracidade histórica tendo em vista serem extremamente sumárias, quase casuais. Pelo contrário, esperamos ter demonstrado que as representaçóes cartográficas selecionadas, vistas, descritas, analisadas e interpretadas criticamente a partir da aferição e contraponto com outros tipos de fontes, notadamente as fontes manuscritas coevas, são em grande parte dignas de credibilidade quanto à realidade que representam, a cidade do Natal e seu entorno na primeira metade do século XVII. As fontes aqui reunidas confirmaram amplamente a maioria das características que apontamos, embasados exclusivamente, e num primeiro momento, tão somente nos desenhos da cidade.

\section{Fontes primárias (publicadas ou não)}

ALBERNAZ I, João Teixeira (o Velho). Descrição de todo o marítimo da Terra de Santa Cruz chamado vulgarmente, o Brasil. Arquivo Nacional da Torre do Tombo.

ANÔNIMO. Atlas da costa do Brasil. Biblioteca Nacional de Portugal. Disponível em: http://purl.pt/23778. Acesso em 5 jun. 2018.

ANÔNIMO. Este livro contém as primeiras relaçóes do descobrimento da costa de Guiné, Mina, Cacheo, Angola, Congo, Bengala e outros reinos e naçóes; seus costumes, exercício e de muitas admiráveis árvores, plantas, animais, aves, peixes, minas de ouro, cobre cristal, sal e outras muitas coisas, dignas de se saber como se verá pelo index seguinte [s.d.].

ANÔNIMO. O Treslado do auto e mais diligências que se fizeram sobre as datas de terras da capitania do Rio Grande, que se tinham dado. Revista do Instituto Histórico e Geográfico do Ceará, Fortaleza, Ano XXIII, 1909, p. 118.

ANÔNIMO. Veroveringe van Rio Grande in Brasil (1633). Estampa completa e recorte ampliado. Fonte: Mapoteca do Itamarati (Ministério das Relaçôes Exteriores). Rio de Janeiro. BARLÉU, Gaspar. História dos feitos recentemente praticados durante oito anos no Brasil. Belo Horizonte: Ed. Itatiaia; São Paulo: Ed. Universidade de São Paulo, 1974.

BLAEU, Joan. Praefectura de Paraiba, et Rio Grande. Atlas Maior Sive Cosmographia Blaviana, Qua Solvm, Salvm, Coelvm, Accuratissime Describuntvr. Amsterdam, 1665. David Rumsey Historical Map Collection. 
BRANDÃO, Ambrósio Fernandes. Diálogo das grandezas do Brasil. Curitiba: Positivo, 2005. BRITO, Bernardo Gomes de (org.). História trágico-marítima. Com outras notícias de naufrágios. v. VII. Lisboa: Escriptorio, 1905.

DO SALVADOR, Frei Vicente. História do Brasil. Rio de Janeiro: Anais da Biblioteca Nacional, v. XIII, 1885-1886.

KNIVET, Anthony. The admirable adventures and strange fortunes of Master Antonie Knivet, which went with Master Thomas Candish in his second voyage to the South Sea. In: PURCHAS, Samuel (ed.). Hakluytus Posthumus or Purchas His Pilgrimes, v. XVI, cap. VII, p. 177-289. Glasgow: James McLehose and Sons, 1906.

LAET, Joannes. História ou anais dos feitos da Companhia Privilegiada das Índias Ocidentais desde o seu começo até o fim do ano de 1636. Livros VIII-X. In: Anais da Biblioteca Nacional, 1916, v. XXXVIII.

MENEZES, Documento 13. Coleção Pernambuco, 12, 02, 2004.

MORENO, Diogo de Campos. Livro que dá razão ao Estado do Brasil. In: SLUITER, Engel. Report on the State of Brazil, 1612. The Hispanic American Historical Review, v. 29, n. 4, p. 518-562, nov. 1949.

MORENO, Diogo de Campos. Relação das Praças Fortes coisas de importância que Sua Majestade tem na costa do Brasil. 1609. Arquivo Nacional da Torre do Tombo.

\section{Referências}

ALBUQUERQUE, Maria Aldaiza Martins; OLIVEIRA, Aldo Gonçalves. Os mapas da geografia e a geografia dos mapas: alguns recortes para análise. Ensino Em Re-Vista, v. 19, n. 2, jul./dez. 2012, p. 363-374.

CASCUDO, Luís da Câmara. História da cidade do Natal. Natal: RN Econômico, 1999.

CINTRA, Jorge Pimentel. Técnicas de leituras de mapas históricos: uma proposta. Revista Brasileira de Cartografia, n. 67/4 773-786, 2015, p. 786.

CRUZ, Luana Honório. Os caminhos do açúcar no Rio Grande do Norte: o papel dos engenhos na formação território potiguar. Tese (doutorado em Arquitetura e Urbanismo) - Programa de Pós-graduaçáo em Arquitetura e Urbanismo, Universidade Federal do Rio Grande do Norte, Natal, 2015.

HARLEY, J. Brian. Deconstructing the map. Evanston, IL: Program of African Studies, Northwestern University, n. 3, p. 10-13, 1992. Disponível em: https:/quod.lib.umich. edu/p/passages/4761530.0003.008/--deconstructing-the- map? rgn=main;view=fulltext. Acesso em: $1^{\circ}$ jan. 2019. 
KNAUSS, Paulo; RICCI, Claudia; CHIAVARI, Maria. Brasil: uma cartografia. 1. ed. Rio de Janeiro: Casa da Palavra, 2010.

LYRA, A. Tavares. História do Rio Grande do Norte. 3. ed. Natal: EDUFRN, 2008.

MEDEIROS FILHO, Olavo de. 8 de dezembro de 1633. O desembarque holandês em Areia Preta. In: EMERECIANO, João Gothardo Dantas. Natal-não-há-tal. Natal: SEMURB, 2007.

MEDEIROS FILHO, Olavo de. Aconteceu na capitania do Rio Grande. Natal: Departamento Estadual de Imprensa, 1997.

MEDEIROS FILHO, Olavo de. Terra natalense. Natal: Fundação José Augusto, 1991.

MENDES, Cândido. Atlas do Império do Brasil. Rio de Janeiro: Lithographia do Instituto Philomathico, 1868.

MOURA, Pedro Rebouças de. Fatos da história do Rio Grande do Norte. Natal: Companhia Editora do Rio Grande do Norte, 1986.

POMBO, Rocha. História do Estado do Rio Grande do Norte. Rio de Janeiro: Annuário do Brasil, 1921.

SLUITER, Engel. Report on the State of Brazil, 1612. The Hispanic American Historical Review, v. 29, n. 4, nov. 1949, p. 518-562. Duke University Press Stable. Disponível em: http://www.jstor.org/stable/2508764.

TEIXEIRA, Rubenilson Brazão. Natal, vila ou cidade? Mercator, Fortaleza, v. 18, e17001, 2019.

TEIXEIRA, Rubenilson Brazão. Da cidade de Deus à cidade dos homens. A secularização do uso, da forma e da função urbana. Natal: EDUFRN, 2009.

TEIXEIRA, Rubenilson Brazão. O poder municipal e as casas de câmara e cadeia. Semelhanças e especificidades do caso potiguar. Natal: EDUFRN, 2012.

TEIXEIRA, Rubenilson Brazão. Terra, casa e produção. A repartição de terras do Rio Grande (1614). Mercator, Fortaleza, v. 13, n. 2, mai./ago. 2014, p. 105-124.

TEIXEIRA, Rubenilson Brazão. Des deux côtes de l'Atlantique. Natal-Dakar dans une perspective comparative. Paris: L'Harmattan, 2018. 